\title{
Identification of Potential Bacillus subtilis Probiotics from Korean Soybean Paste and Their Antimicrobial and Immune Activities
}

\author{
Weon Taek Seo ${ }^{1}$, Sang Hae Nam${ }^{1}$, Chang Kwon $\mathrm{Lee}^{2}$, and Kye Man Cho ${ }^{1 \dagger}$ \\ ${ }^{I}$ Department of Food Science, Jinju National University, Gyeongnam 660-758, Korea \\ ${ }^{2}$ Soy Sauce and Paste Techno-Research Laboratory, Mong-Go Food Company, Gyeongnam 641-847, Korea
}

\begin{abstract}
The potential probiotic of a total of 15 Bacillus species isolated from Korean soybean paste (doenjang) was evaluated. Among those tested, the CSY191 and CSY388 strains were selected as probiotic bacteria due to their acid and bile tolerance, respectively. These strains were classified as Bacillus subtilis based on morphological, physiological, and chemotaxonomic features as well as on phylogenetic analysis based on their 16S rDNA sequences. These strains CSY191 and CSY388 showed a significant survival with rate range of 30.0 to $58.3 \%$ and of $31.0 \%$ to $58.1 \%$, respectively, under artificial gastric acidic conditions at pH 3.0. These CSY191 and CSY388 strains appeared to have high antimicrobial activity against Salmonella Typhimurium, Bacillus cereus and Listeria monocytogenes. Also, methanol extractions (surfactin-like compounds) of strain CSY191 and strain CSY388 activated RAW264.7 microphages and induced the production of nitric oxide (NO) in a concentration-dependent manner, respectively. Therefore, strain CSY191 and strain CSY388 can be used as potential probiotics.
\end{abstract}

Key words: probiotics, Bacillus subtilis, antimicrobial activity, immune activity

\section{INTRODUCTION}

Probiosis, although not a new concept, has recently begun to receive an increasing level of scientific interest. Probiosis is defined an association of two organisms that enhances the life processes of both. Probiotics are generally defined as live microbial feed supplements that can benefit the host by improving its intestinal balance (1) through immunomodulation, competitive exclusion of gastrointestinal pathogens, and secretion of antimicrobial compounds, which suppress the growth of harmful bacteria $(1,2)$. Lactobacilli, streptococci, bifidobacteria, enterococci, and bacilli are the bacteria that are most often used in the production of probiotics (3). Although studies have demonstrated a direct probiotic effect of Bacillus spores, preliminary studies with poultry provided evidence of a competitive exclusion of Escherichia coli $\mathrm{O} 78: \mathrm{K} 80$ by B. subtilis (4), and a number of studies have demonstrated that harmful bacteria are suppressed by various Bacillus spore formers $(2,5)$. Pinchuk et al. (6) reported the characterization of an antibiotic produced by the $B$. subtilis strain found in the commercial product Biosporin, which is known to inhibit the growth of Helicobacter pylori. Recently, Lim and Kim (7) reported the selection and characterization of the bacteriocin produced by the B. subtilis BP6. In addition, a large number of Bacillus products are used as 'novel foods' or as dietary supplements, with claims of enhancing restoring the natural microflora to the gut and well-being of the consumer (8).

Fermented soybean foods, such as soybean pastes (doenjang and cheonggukjang), and soybean sauce (kanjang), have been served as side dishes for thousands of years, providing a major source of protein for Koreans. The production of Korean traditional soybean paste and sauce from the fermentation of soybeans depends predominantly on Bacillus species, notably $B$. subtilis, B. pumilus, B. licheniformis, and B. amyloquefencies (9). Foods derived from fermented soybeans have attracted considerable interest due to their excellent nutritional value and their beneficial impact on human health, such as acting as anticarcinogenic agents and as antioxidants $(10,11)$. These foods are also known to play a role in both the prevention of heart attacks and the prevention of blood coagulation (12).

In the present study, the isolation of potential probiotics and classification of the isolates was performed by determining their morphological, physiological, and chemotaxonomic features, as well as by conducting phylogenetic analyses. In addition, the antimicrobial and im- 
munological activities of potential B. subtilis probiotics were demonstrated.

\section{MATERIALS AND METHODS}

\section{Isolation of Bacillus strains}

Traditional Korean fermented soybean pastes (deonjang) were collected from both the local market and from Korean homes. Collected samples were diluted with $0.85 \% \mathrm{NaCl}$ and, subsequently, $0.1 \mathrm{~mL}$ of the diluted suspension was plated on TSA (Difco, Detroit, MI, USA) plates. After the plates were incubated at $37^{\circ} \mathrm{C}$ for $48 \mathrm{hr}$, a distinctive single colony was selected as a pure isolate on each TSA plate. Isolates were stored until needed at $-80^{\circ} \mathrm{C}$ with $20 \%$ sterile glycerol.

\section{Determination of tolerance to acid, artificial gastric acid, and bile acid}

The method described by Cho (13) was used to determine the tolerances to acid, artificial gastric acid, and bile acid. For determination of acid tolerance, isolated Bacillus strains were grown in TSB at $37^{\circ} \mathrm{C}$ for $48 \mathrm{hr}$ and were diluted to $10^{6} \mathrm{CFU} / \mathrm{mL}$ in fresh TSB adjusted to $\mathrm{pH} 3.0$ with hydrochloric acid $(3 \mathrm{M})$. Diluted cells were incubated for 3 and $6 \mathrm{hr}$ at $37^{\circ} \mathrm{C}$. After incubation, the cells were serially diluted in a phosphate buffer $(0.1$ $\mathrm{M}, \mathrm{pH}$ 6.2) to neutralize the medium acidity, and the viable cells on the TSA plate were counted after $48 \mathrm{hr}$ of incubation at $37^{\circ} \mathrm{C}$. The survival rate was calculated as the percentage of Bacillus sp. colonies grown on the TSA plate compared to the initial bacterial concentration.

For determination of the artificial gastric acid tolerance, an artificial gastric juice was created by adding $1 \%$ pepsin (Sigma-Aldrich, St. Louis, MO, USA) to the TSB at $\mathrm{pH}$ 3.0. Cells grown in TSB at $37^{\circ} \mathrm{C}$ for $48 \mathrm{hr}$ were diluted to $10^{6} \mathrm{CFU} / \mathrm{mL}$ in fresh artificial gastric acids adjusted to $\mathrm{pH}$ 3.0. Diluted cells were incubated for 3 and $6 \mathrm{hr}$ at $37^{\circ} \mathrm{C}$. After incubation, the cells were serially diluted in phosphate buffer $(0.1 \mathrm{M}, \mathrm{pH}$ 6.2) to neutralize the acidity of the medium. The viable cells were then incubated on the TSA plate for $48 \mathrm{hr}$ at $37^{\circ} \mathrm{C}$ and were counted. The survival rate was calculated as the percentage of Bacillus sp. colonies grown on the TSA plate compared to the initial bacterial concentration.

For determination of bile tolerance, $15 \mu \mathrm{L}$ of the cells grown in TSB at $37^{\circ} \mathrm{C}$ for $48 \mathrm{hr}$ (equivalent to $10^{6}$ $\mathrm{CFU} / \mathrm{mL}$ ) was spotted on TSA plates containing oxgall bile (Sigma-Aldrich) at different concentrations (1 4\% $\mathrm{w} / \mathrm{v})$. The plates were incubated at $37^{\circ} \mathrm{C}$ for 5 days. The minimum inhibitory concentration (MIC) of the bile for the Bacillus strain was determined as the lowest concentration that completely inhibited cell growth as judged from visual examination.

The two potential probiotics Bacillus sp. CSY191 and CYS388 were screened from Korean soybean paste (doenjang) and compared to previously reported activities of the potential probiotic B. subtilis CS90 (13).

\section{Morphological and physiological characteristics}

Cell morphology was examined by light microscopy after Gram staining, and flagellum type was determined by transmission electron microscopy (JEM 1010, JEOL, Tokyo, Japan) using preparations negatively stained with $1 \%$ phosphotungstic acid. Phenotypic characterization was carried out using standard methods and API50CHB kits (bioMérieux, Montalieu Vercieu, France). The methods described by Cowan and Steel (14) were used for the following physiological tests: catalase and oxidase activity as well as hydrolyses of skim milk, gelatin, casein, cellulose, and starch. Growth in response to various concentrations of $\mathrm{NaCl}$ and temperatures was determined using TSB as a basal medium.

\section{Chemotaxonomy and 16S rDNA analysis}

The biomass for cellular fatty acid analysis was prepared from a culture grown on a TSA plate for $24 \mathrm{hr}$ at $37^{\circ} \mathrm{C}$. Fatty acid methyl esters were prepared using the method described in the manual of the MIDI Microbial Identification System. The resultant esters were separated using a gas chromatograph fitted with a phenylmethyl silicone-fused silica capillary column $(25 \mathrm{~m}$ $\times 0.2 \mathrm{~mm}$; Hewlett Packard, Palo Alto, CA, USA).

The 16S rDNA of strain CSY191 and strain CSY388 were amplified by PCR. PCR amplification was performed as follows: 30 cycles of denaturation at $90^{\circ} \mathrm{C}$ for $1 \mathrm{~min}$, annealing at $55^{\circ} \mathrm{C}$ for $30 \mathrm{sec}$, and extension at $72^{\circ} \mathrm{C}$ for $1 \mathrm{~min}$. The PCR primers used to amplify the 16S rDNA fragments were the bacterial-specific 5'-CGGAGAGTTTGATCCTGG-3' (1BF, forward) and 5'-TACGGCTACCTTGTTACGAC-3' (2BR, reverse) primers (13). Amplified 16S rDNA fragments were used as the sequencing templates. Nucleotide sequences were determined by the dideoxy-chain termination method using a PRISM Ready Reaction Dye terminator/primer cycle sequencing kit (Perkin-Elmer, Norwalk, CT, USA). Assembly of the nucleotide sequences was performed using the DNAMAN analysis system (Lynnon Biosoft, Quebec, Canada). All reference sequences were obtained from the National Center for Biotechnology Information and Ribosomal Database Project databases. The 16S rDNA similarity values were determined based on alignments, and the evolutionary distances were calculated. Phylogenetic analysis was performed using the neighbor-joining method (15). Bootstrap analysis was performed on the data (re-sampled 1,000 times) using the 
DNAMAN analysis system (Lynnon Biosoft). Nucleotide sequence data reported for the $16 \mathrm{~S}$ rDNA of the strains CSY191 and CSY388 are available in the GenBank database under the accession numbers HQ328857 and HQ328856, respectively.

\section{Preparation of methanol extractions}

Cells were grown in Number 3 medium (No. 3: 10 g polypeptone, $10 \mathrm{~g}$ glucose, $1 \mathrm{~g} \mathrm{KH}_{2} \mathrm{PO}_{4}$, and $0.5 \mathrm{~g}$ $\mathrm{MgSO}_{4} \cdot 7 \mathrm{H}_{2} \mathrm{O}$ per liter, $\mathrm{pH} 6.8$ ) at $30^{\circ} \mathrm{C}$. After 3 days of cultivation, the supernatant was collected by centrifugation and was adjusted to $\mathrm{pH} 2.0$ using $2 \mathrm{~N} \mathrm{HCl}$. The resultant precipitate was collected by centrifugation and extracted three times with methanol $(\mathrm{MeOH})$. The $\mathrm{MeOH}$ extractions (surfactin-like compound) were concentrated and then dissolved in $\mathrm{MeOH}$.

\section{Antimicrobial activity}

Thirteen food-borne pathogenic bacteria, including Escherichia coli KCTC 1682, Pseudomonas aeruginosa KCTC 1750, Salmonella enterica KCTC 12456, Salmonella Enteritidis KCTC 12400, Salmonella Typhimurium KCTC 1925, Shigella flexineri KCTC 2008, Shigella sonnei KCTC 2518, Bacillus cereus KCTC 1012, Listeria innocua KCTC 3586, Listeria ivanovii KCTC 3444, Listeria monocytogenes KCTC 3569, Staphylococcus aureus KCTC 1916, and Staphylococcus epidermidis KCTC 1917, were used as test organisms. These test organisms were grown on the TSA plates at $37^{\circ} \mathrm{C}$.

Fifty microliters of the $\mathrm{MeOH}$ extractions $(100 \mu \mathrm{g} /$ $\mathrm{mL}$ ) were applied to $8-\mathrm{mm}$ sterile paper disks, and the disk was placed on a TSA plate, which was spread with a test organism, for the antibacterial activity assay. After $48 \mathrm{hr}$ of incubation at $37^{\circ} \mathrm{C}$, antibacterial activity was measured as the diameter of the clear zone formed.

\section{Immune activity}

RAW264.7 murine macrophage-like cells (KCLB 40071) were obtained from the Korean Cell Line Bank in Seoul, Korea. Cells were incubated in Dulbecco's modified Eagle's medium (DMEM, Difico, Detroit, MI) supplemented with $10 \%(\mathrm{v} / \mathrm{v})$ fetal bovine serum and penicillin $(100 \mathrm{IU} / \mathrm{mL})$ and streptomycin $(100 \mu \mathrm{g} / \mathrm{mL})$ at $37^{\circ} \mathrm{C}$ in humidified air with $5 \%(\mathrm{v} / \mathrm{v}) \mathrm{CO}_{2}$. RAW264.7 cells were seeded at $2 \times 10^{5}$ cells $/ \mathrm{mL}$ on a 96-well plate, incubated for $24 \mathrm{hr}$. After $24 \mathrm{hr}$, the cultured cancer cells were washed with phosphate buffered saline (PBS) buffer ( $\mathrm{pH}$ 7.4), and then fresh medium was added on a 96-well plate. To examine nitric oxide production, this plate was treated with various concentrations of $\mathrm{MeOH}$ extractions $(20 \mu \mathrm{L})$ from CS90, CSY191 and CSY388 strains or $1 \mu \mathrm{g} / \mathrm{mL}$ lipopolysaccharide (LPS; from E. coli Serotype O111:B4; Sigma-Aldrich) in PBS buffer (pH
7.4) for $24 \mathrm{hr}$. As control, cells were treated with only PBS buffer ( $\mathrm{pH}$ 7.4) and mycoplasma for $24 \mathrm{hr}$. The cell supernatants $(100 \mu \mathrm{L})$ were added to 96 -well plates with the Griess reagent $[1 \%(\mathrm{w} / \mathrm{v})$ sulfanilamide in $5 \%$ $\mathrm{H}_{3} \mathrm{PO}_{4}: 0.1 \%$ (w/v) $N$-[1-naphthyl]-ethylenediamine in $\left.\mathrm{H}_{2} \mathrm{O}=1: 1\right](100 \mu \mathrm{L})$, and absorbance was measured using a microplate reader (Bio-Rad, Philadelphia, PE, USA) at $570 \mathrm{~nm}$. Sodium nitrite was used as a standard.

\section{Statistical analysis}

Data were expressed as means \pm SD (standard deviation) of three replicates. The differences among all groups were analyzed by one-way analysis of variance (ANOVA) using the SPSS version 12.0 (SPSS Inc., Chicago, IL, USA). In addition, when significant difference was indicated, Duncan's multiple range test was performed to separate difference; the level of significance was $\mathrm{p}<0.05$.

\section{RESULTS AND DISCUSSION}

Survival rate of isolated Bacillus strains under gastrointestinal tract conditions

Survival rates of several Bacillus strains under acidic and artificial gastric conditions are shown in Table 1. In general, survival rates of the isolated Bacillus strains decreased with the lapse of time under acidic conditions. Among the strains isolated, CSY191 and CSY388 showed significantly high survival rate. Survival rate of CS90, as previously reported (13), and strain CSY191

Table 1. Survival rates of isolated strains from different soybean fermented foods under acidic and artificial gastric acidic conditions after 3 and $6 \mathrm{hr}$ of incubation ${ }^{1)}$

\begin{tabular}{|c|c|c|c|c|}
\hline \multirow{3}{*}{$\begin{array}{l}\text { Isolated } \\
\text { strain }\end{array}$} & \multicolumn{4}{|c|}{ Survival rate $(\%)$} \\
\hline & \multicolumn{2}{|c|}{ Acid (pH 3.0) } & \multicolumn{2}{|c|}{ Artificial gastric acid $(\mathrm{pH} 3.0$} \\
\hline & 3 & 6 & 3 & 6 \\
\hline $\mathrm{CS} 90^{2)}$ & 67.0 & 43.0 & 57.4 & 28.1 \\
\hline CSY22 & 40.7 & 22.5 & 25.6 & 4.2 \\
\hline CSY49 & 45.8 & 34.6 & 35.6 & 10.9 \\
\hline CSY135 & 48.2 & 35.4 & 39.1 & 28.2 \\
\hline CSY191 & 68.8 & 65.1 & 58.3 & 30.0 \\
\hline CSY382 & 42.0 & 35.3 & 20.0 & 14.8 \\
\hline CSY383 & 10.2 & 1.0 & 4.6 & 0 \\
\hline CSY384 & 37.7 & 16.6 & 9.0 & 6.7 \\
\hline CSY385 & 38.5 & 16.7 & 3.3 & 2.5 \\
\hline CSY386 & 8.4 & 1.0 & 2.3 & 0 \\
\hline CSY387 & 13.7 & 1.9 & 0.6 & 0.2 \\
\hline CSY388 & 66.0 & 42.8 & 58.1 & 31.0 \\
\hline CSY391 & 38.9 & 21.5 & 6.2 & 1.4 \\
\hline CSY393 & 39.0 & 26.9 & 5.0 & 3.3 \\
\hline CSY398 & 44.7 & 23.6 & 23.8 & 16.8 \\
\hline
\end{tabular}

${ }^{1)}$ Each isolated Bacillus sp. was tested in triplicate for its tolerance in acidified and artificial gastric acidified TSBs.

${ }^{2)}$ Cho (13) previously reported the potential probiotic $B$. subtilis CS90. 
and strain CSY388 under acidic conditions of $\mathrm{pH} 3.0$ after $3 \mathrm{hr}$ were $67.0 \%, 68.8 \%$, and $66.0 \%$, respectively. B. subtilis CS90 and Bacillus sp. CSY191 and CSY388 showed significantly higher survival rates of $57.4 \%$, $58.3 \%$ and $58.1 \%$, respectively, under artificial gastric acidic conditions of pH 3.0 after $3 \mathrm{hr}$. All strains were able to withstand bile concentrations higher than $4.0 \%$ (data not shown).

Bacillus probiotics differ in many characteristics from those based on lactic acid bacteria $(16,17)$. Whereas lactobacilli represent a normal resident GI microflora of humans, the saprophytic gastrointestinal tract (GIT) bacteria of Bacillus genera belong only to the transitory GI bacteria. Thus, the use of Bacillus products raised a number of questions, including their safety. Over the past three decades, this genus has expanded to include more than 100 species (19). However, only a few of these species are used as probiotics for humans, including the following: B. subtilis, B. licheniformis, B. calusii, B. coagulans, $B$. cereus, B. pumilus, $B$. laterosporus, as well as some invalid species called $B$. toyoi and $B$. polyfermenticus $(2,3,18)$. On the contrary, Sorokulova et al. (19) reported that the B. subtilis strains may be considered non-pathogenic and safe for human consumption. Previously, Cho (13) suggested that the isolated B. subtilis from soybean paste was able to be used as probiotics for humans and foods.

Identification of strain CSY191 and strain CSY388

The morphological, biochemical, and physiological characteristics of CSY191 and CSY388 were analyzed (Table 2). After $24 \mathrm{hr}$ of incubation at $37^{\circ} \mathrm{C}$, these strains were Gram-positive and rod-shaped, measuring 0.6 to $0.8 \times 2$ to $3 \mu \mathrm{m}$ (CS90 and CSY388 strains) and 0.6 to $0.8 \times 2$ to $3 \mu \mathrm{m}$ (CSY191 strain). Three strains are facul- tatively anaerobic and grew at 10 to $50^{\circ} \mathrm{C}$, with an optimum growth temperature range of 30 to $37^{\circ} \mathrm{C}$. These strains grew in the presence of 0 to $15 \%(\mathrm{w} / \mathrm{v}) \mathrm{NaCl}$ and showed catalase and oxidase activities but no urease activity. Skim milk, gelatin, cellulose, and starch were hydrolyzed by the strains. Reactions for the oxidation and fermentation of carbohydrates as the sole carbon sources are shown in Table 2. Both CSY191 and CSY388 strains were able to use lactose as the sole carbon source, but strain CS90 was not. Also, strain CSY388 can use galactose and D-turanose, but the other two strains cannot use these carbon sources. The cellular fatty acid profiles of strain CSY191 and strain CSY388 include large amounts of saturated and branched fatty acids, with anteiso- $\mathrm{C}_{15: 0}$ (data not shown).

Morphological, biochemical, and physiological analyses clearly demonstrated that the strains were members of the genus Bacillus. From chemotaxonomic data, the fact that anteiso- $\mathrm{C}_{15: 0}$ was the major cellular fatty acid indicates these two strains were belong to the genus Bacillus. In addition, results of the physiological properties indicated that strain CSY191 and strain CSY388 differed from the other species of Bacillus in their carbohydrate utilization pattern.

A complete 16S rDNA sequence of the CSY191 (1,532 bp; accession number; HQ328857) and CSY388 (1,532 bp; accession number; HQ328856) were determined. A phylogenetic tree was constructed using the sequence data shown that included the CSY191 and CSY388 strains grouped within the evolutionary radiation, encompassing the genus Bacillus and occupying a distinct phylogenetic position within this genus. The levels of 16S rRNA similarity between the strains CSY191 and CSY388 and the Bacillus species ranged from 93.1 to $99.9 \%$. The highest

Table 2. Comparison of phenotypic characteristics of probiotic Bacillus subtilis

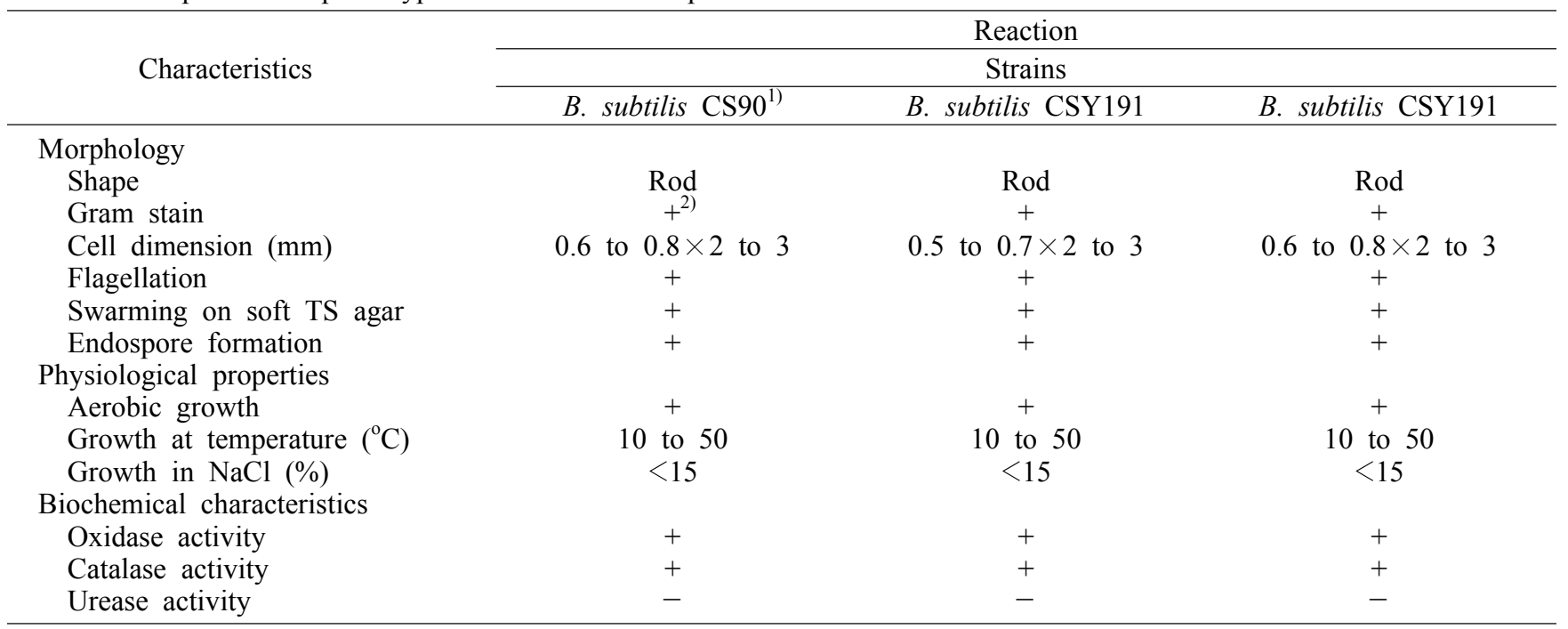


Table 2. Continued

\begin{tabular}{|c|c|c|c|}
\hline \multirow{3}{*}{ Characteristics } & \multicolumn{3}{|c|}{ Reaction } \\
\hline & \multicolumn{3}{|c|}{ Strains } \\
\hline & B. subtilis CS90 & B. subtilis CSY191 & B. subtilis CSY191 \\
\hline \multicolumn{4}{|l|}{ Hydrolysis of } \\
\hline Skim milk & + & + & + \\
\hline Casein & - & - & - \\
\hline Gelatin & + & + & + \\
\hline Cellulose & + & + & + \\
\hline Starch & + & + & + \\
\hline \multicolumn{4}{|l|}{ Carbohyrates } \\
\hline Glycerol & + & + & + \\
\hline Ertythritol & - & - & - \\
\hline D-arabinose & - & - & - \\
\hline L-arabinose & + & + & + \\
\hline Ribose & + & + & + \\
\hline D-xylose & + & + & + \\
\hline L-xylose & - & - & - \\
\hline Adonitol & - & - & - \\
\hline$\beta$ methyl-xyloside & - & - & - \\
\hline Galactose & - & - & + \\
\hline D-glucose & + & + & + \\
\hline D-fructose & + & + & + \\
\hline D-mannose & + & + & + \\
\hline L-sorbose & - & - & - \\
\hline Rhamnose & - & - & - \\
\hline Dulcitol & - & - & - \\
\hline Inositol & + & + & + \\
\hline Mannitol & + & + & + \\
\hline Sorbitol & + & + & + \\
\hline$\alpha$ methyl-D-mannoside & - & - & - \\
\hline$\alpha$ methyl-D-glucoside & + & + & + \\
\hline$N$ acetyl glucosamine & - & - & - \\
\hline Amygdaline & + & + & + \\
\hline Arbutine & + & - & - \\
\hline Esuline & + & + & + \\
\hline Salicine & + & + & + \\
\hline Cellobiose & + & + & + \\
\hline Maltose & + & + & + \\
\hline Lactose & - & + & + \\
\hline Melibiose & + & + & + \\
\hline Saccharose & + & + & + \\
\hline Trehalose & + & + & + \\
\hline Inuline & - & - & + \\
\hline Melezitose & - & - & - \\
\hline D-raffinose & + & + & + \\
\hline Amidon & + & + & + \\
\hline Glycogen & + & + & + \\
\hline Xylitol & - & - & - \\
\hline$\beta$ gentiobiose & + & - & + \\
\hline D-turanose & - & - & + \\
\hline D-lyxose & - & - & - \\
\hline D-tagatose & - & - & - \\
\hline D-fucose & - & - & - \\
\hline L-fucose & - & - & - \\
\hline D-arabitol & - & - & - \\
\hline L-arabitol & - & - & - \\
\hline Gluconate & - & - & - \\
\hline 2 ceto-gluconate & - & - & - \\
\hline 2 ceto-gluconate & - & - & - \\
\hline
\end{tabular}

${ }^{1)}$ Cho (13) previously reported the potential probiotic B. subtilis CS90.

${ }^{2)}+$, positive reaction; - , negative reaction. 


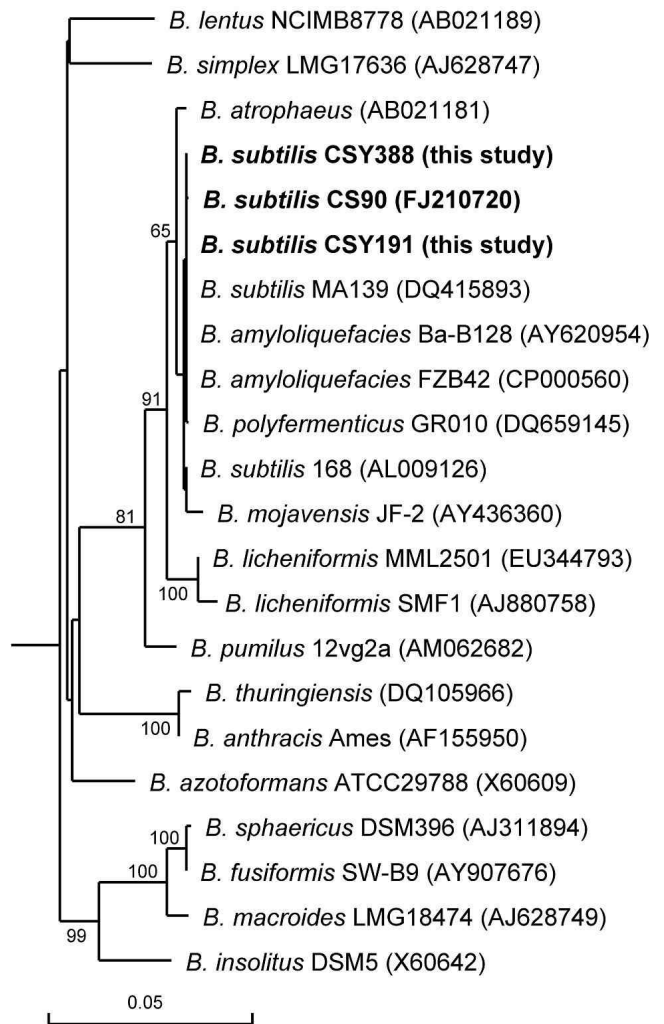

Fig. 1. Phylogenetic relationships of the CS90, CSY191 and CSY388 strains and other closely related Bacillus sp. based on $16 \mathrm{~S}$ rDNA. Number above each node us the confidence level $(\%)$ generated from 1,000 bootstrap trees. The scale bar is in fixed nucleotide substitutions per sequences positions.

16S rDNA sequence similarity (99.9\%) was observed between CSY191 strain, CSY388 strain, and B. subtilis
MA139, respectively (Fig. 1). The present phylogenetic study clearly established that the CSY191 and CSY388 are closely related to $B$. subtilis.

\section{Antimicrobial activity against food-bome pathogenic bacteria}

The $\mathrm{MeOH}$ extractions by the potential probiotic three $B$. subtilis strains showed a broad range of antibacterial activities (Table 3). All three B. subtilis strains showed antibacterial activities against $S$. Enteritidis, $S$. Typhimurium, S. sonnei, B. cereus, L. monocytogenes, and $S$. aureus. In particular, B. subtilis CSY191 showed inhibitory activities against all Gram-negative bacteria tested, such as E. coli, $P$. aeruginosa, $S$. enterica, $S$. Enteritidis, S. Typhimurium, S. flexineri, and S. sonnei, known as the main pathogens causing diarrhea in humans $(11,20,21)$. An antimicrobial activity is considered to be one of the major functions of probiotics; therefore, this function may be one of the principal criteria applied for the screening of potential probiotic strains $(7,8,13$, $16,22)$.

The antimicrobial agents from probiotic Bacillus strains are considered one of the principal mechanisms (microbial interference therapy) for inhibiting pathogenic microorganisms in GITs. Bacillus species produce a large number of antimicrobials (18), including bacteriocins and bacteriocin-like inhibitory substances (e.g., subtillin and coagulin) as well as antibiotics (e.g., surfactin, iturin, and bacilysin) (8). In particular, B. subtilis produces antimicrobial lipopeptides, such as surfactin,

Table 3. Antibacterial activity of probiotic Bacillus subtilis when incubated with 13 food-borne pathogenic bacteria

\begin{tabular}{|c|c|c|c|}
\hline \multirow{3}{*}{$\begin{array}{c}\text { Food-borne } \\
\text { pathogenic microorganisms }\end{array}$} & \multicolumn{3}{|c|}{ Inhibitory zone ${ }^{1)}(\mathrm{mm})$} \\
\hline & \multicolumn{3}{|c|}{ Strains } \\
\hline & B. subtilis $\mathrm{CS} 90^{2)}$ & B. subtilis CSY191 & B. subtilis CSY388 \\
\hline \multicolumn{4}{|l|}{ Gram-negative bacteria } \\
\hline E. coli $\mathrm{KCTC}^{3)} 1682$ & $-{ }^{4)}$ & 8.4 & 8.7 \\
\hline P. aeruginosa KCTC 1750 & 13.2 & 15.4 & - \\
\hline S. enterica KCTC 12450 & 9.6 & 8.6 & - \\
\hline S. Enteritidis KCTC 12400 & 13.4 & 18.6 & 16.7 \\
\hline S. Typhimurium KCTC 1926 & 22.0 & 24.3 & 18.6 \\
\hline S. flexineri KCTC 2008 & 12.4 & 16.2 & - \\
\hline S. sonnei KCTC 2518 & 14.6 & 9.0 & 24.2 \\
\hline \multicolumn{4}{|l|}{ Gram-positive bacteria } \\
\hline B. cereus KCTC 1012 & 24.9 & 25.4 & 23.6 \\
\hline L. innocua КСТC 3586 & - & - & 12.6 \\
\hline L. ivanovii KCTC 3444 & 12.2 & 21.1 & - \\
\hline L. monocytogenes KCTC 3569 & 21.7 & 24.3 & 23.2 \\
\hline S. aureus KCTC 1916 & 12.7 & 24.5 & 11.6 \\
\hline S. epidermidis KCTC 1917 & 11.8 & 8.5 & - \\
\hline
\end{tabular}

${ }^{1)}$ The antibacterial activity was estimated by measuring the diameter of the clear zone (including paper disks, $8 \mathrm{~mm}$ diameter) of growth inhibition.

${ }^{2)}$ Cho (13) previously reported the potential probiotic B. subtilis CS90.

${ }^{3)}$ KCTC, Korea Collection for Type Culture.

4) - , no inhibition. 
fengycin, iturin, bacillomycins, mycosubtilin, and plipastatin (23-25). Also, Teo and Tan (26) reported that the antimicrobial factor, bacteriocin, produced by a probiotic B. subtilis PB6. Recently, an antibiotic compound (nonproteolytic bacteriocin BP6) isolated from a probiotic $B$. subtilis BP6 strain was found to have antimicrobial activity against Salmonella Gallinarum (7).

\section{Immune activity}

The effect of $\mathrm{MeOH}$ extractions (surfactin-like compounds) on NO production in RAW264.7 macrophages was examined using a Griess reaction (27). After $24 \mathrm{hr}$ of exposure $(10,50,100,250$ or $500 \mu \mathrm{g} / \mathrm{mL})$, RAW264.7 macrophages showed a concentration-dependent production of NO. In particular, a $\mathrm{MeOH}$ extraction of the CSY388 strain produced more $\mathrm{NO}$ than $\mathrm{MeOH}$ extractions of strain CS90 and strain CSY191 (Fig. 2). This result suggests that strain CSY191 more may have greater potential to affect the immune system than strain CS90 and strain CSY191.

Stimulation of the immune system or immunomodulation is considered an important mechanism to support probiosis (8). Surfactin exhibits diverse biological activities, including antitumoral (28), antiviral (29), antibacterial (30), hemolytic (31), and fibrinolytic activities (32). Previously, Hwang et al. $(33,34)$ reported that surfactin inhibited mycoplasma-induced NO production in LPS-stimulated RAW264.7 cells. In addition, natto, a food made by fermenting cooked soybeans with $B$. subtilis (natto) or B. subtilis (var. natto), has been shown

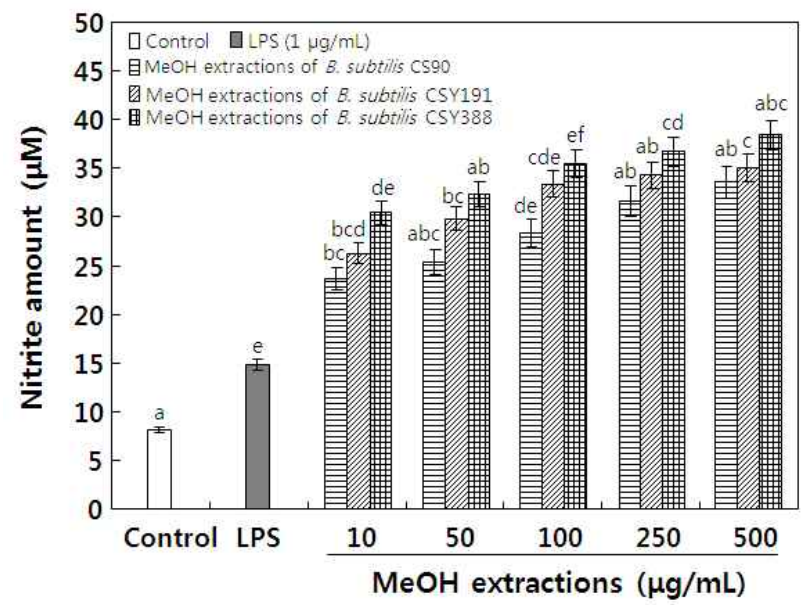

Fig. 2. Effect of $\mathrm{MeOH}$ extractions from B. subtilis CS90, CSY191 and CSY388 on nitric oxide (NO) production in RAW264.7 macrophages. As control, cells were treated with only PBS buffer ( $\mathrm{pH}$ 7.4). RAW264.7 cells were treated with either LPS $(0.1 \mu \mathrm{g} / \mathrm{mL})$ or $\mathrm{MeOH}$ extractions $(10,50,100$,

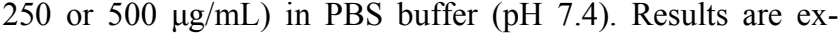
pressed as mean $\pm \mathrm{SD}(\mathrm{n}=3)$, and different letters are significantly different $(\mathrm{p}<0.05)$ by Duncan's multiple range test. to have probiotic properties, and the $B$. subtilis (var. natto) component is thought to stimulate the immune system and produce vitamin K2 (8). To the best of our knowledge, this is the first report on the immune activities by the isolation of the potential probiotic $B$. subtilis from doenjang.

In conclusion, the present study identified probiotic activities of B. subtilis CSY191 and B. subtilis CSY388 against food-borne pathogenic bacteria, such as $S$. enteric, $S$. Enteritidis, $S$. Typhimurium, B. cereus, L. ivanovii, L. monocytogenes, $S$. aureus, and $S$. epidermidis. In addition, methanol extractions (surfactin-like compounds) from strain CSY191 and strain CSY388 activated RAW264.7 microphages and induced the production of NO. In particular, B. subtilis CSY191 had stronger antimicrobial activity against all Gram-negative bacteria than other strains. Furthermore, B. subtilis CSY388 showed the highest the immune activity among the tested strains. From these results, we suggests that B. subtilis CSY191 and B. subtilis CSY388 was possible to use the potential probiotics.

\section{ACKNOWLEDGMENTS}

This work was supported by Jinju National University Grant and Basic Science Research Program through the National Research Foundation of Korea (NRF) funded by the Ministry of Education, Science and Technology (grant number 2010-0022508), Republic of Korea.

\section{REFERENCES}

1. Fuller R. 1989. Probiotics in man and animals. J Appl Bacteriol 66: 365-378.

2. Duc LH, Hong HA, Barbosa TM, Henriques AO, Cutting SM. 2004. Characterization of Bacillus probiotics available for human use. Appl Environ Microbiol 70: 21612171.

3. Kim KK, Kim MJ, Kim DH, Park YS, Kang JS. 2009. Characterization of Bacillus polyfermenticus KJS-2 as a probiotic. J Microbiol Biotechnol 19: 1013-1018.

4. La Ragione RM, Casula G, Cutting SM, Woodward SM. 2001. Bacillus subtilis spores competitively exclude Escherichia coli 070:K80 in poultry. Vet Microbiol 79: 133142.

5. Vaseeharan B, Ramasamy P. 2003. Control of pathogenic Vibrio spp. by Bacillus subtilis BT23, a possible probiotic treatment for black tiger shrimp Penaeus monodon. Lett Appl Microbiol 36: 83-87.

6. Pinchuk IV, Bressollier P, Verneuil B, Fenet B, Sorokulova IB, Megraud F, Urdaci MC. 2001. In vitro anti-Helicobacter pylori activity of the probiotic strain Bacillus subtilis 3 is due to secretion of antibiotics. Antimicrob Agents Chemother 45: 3156-3161.

7. Lim JH, Kim SD. 2009. Selection and characterization of the bacteriocin-producing bacterium, Bacillus subtilis BP6 isolated from chicken gut against Salmonella gallinarum 
casuing fowl-typhus. J Korean Soc Appl Biol Chem 52: 80-87.

8. Hong HA, Duc LH, Cutting SM. 2005. The use of bacterial spore formers as probiotics. FEMS Microbiol Rev 29: 813-835.

9. Cho KM, Math RK, Hong SY, Islam SMA, Mandanna DK, Cho JJ, Yun MG, Kim JM, Yun HD. 2009. Iturin produced by Bacillus pumilus HY1 from Korean soybean sauce (kanjang) inhibits growth of aflatoxin producing fungi. Food Cont 20: 402-406.

10. Kim NY, Song EJ, Kwon DY, Kim HP, Heo MY. 2008. Antioxidant and antigenotoxic activities of Korean fermented soybean. Food Chem Toxicol 46: 1184-1189.

11. Jung KO, Park SY, Park KY. 2006. Longer aging time increases the anticancer and antimetastatic properties of doenjang. Nutrition 22: 539-545.

12. Cho KM, Seo WT. 2007. Bacterial diversity in a Korean traditional soybean fermented foods (doenjang and ganjang) by $16 \mathrm{~S}$ rRNA gene sequence analysis. Food Sci Biotechnol 16: 320-324.

13. Cho KM. 2008. Characterization of potential probiotics Bacillus subtilis CS90 from soybean paste (doenjang) and its antimicrobial activity against food-borne pathogens. $J$ Appl Biol Chem 51: 285-291.

14. Cowan ST, Steel KJ. 1965. Manual for the identification of medical bacteria. Cambridge University Press, London, UK.

15. Saito N, Nei M. 1987. The neighbor-joining method: A new method for reconstructing phylogenetic trees. Mol Biol Evol 4: 406-425.

16. Chang YH, Kim JK, Kim HJ, Kim WY, Kim YB, Park YH. 2001. Selection of a potential probiotic Lactobacillus strain and subsequent in vivo studies. Antonie van Leeuwenhoek 80: 193-199.

17. Kim SJ. 2005. Potential probiotic of lactic acid bacteria isolated from kimchi. Food Sci Biotechnol 14: 503-508.

18. Urdaci MC, Pinchuk I. 2004. Antimicrobial activity of Bacillus probiotics. In Bacterial Spore Formers: Probiotics and Emerging Applications. Ricca E, Henriques AO, Cutting SM, eds. Horizon Bioscience, Norfolk, UK. p 93-106.

19. Sorokulova IB, Pinchuk IV, Denayrolles M, Osipova IG, Huang JM, Cutting SM, Urdaci MC. 2008. The safety of two Bacillus probiotic strains for human use. Dig Dis Sci 53: 954-963.

20. Li Y, Zhuang S, Mustapha A. 2005. Application of a multiplex PCR for the simultaneous detection of Escherichia coli O157:H7, Salmonella and Shigella in raw and readyto-eat meat products. Meat Sci 71: 402-406.

21. Gast RK, Holt PS, Guraya R. 2006. Effect of refrigeration on in vitro penetration of Salmonella Enteritidis through the egg yolk membrane. J Food Prot 69: 1426-1429.

22. Guo X, Li D, Lu W, Piao X, Chen X. 2006. Screening of Bacillus strains as potential probiotics and subsequent confirmation of the in vivo effectiveness of Bacillus subtilis MA139 in pigs. Antonine van Leeuwenhoek 90: 139146.
23. Vater J, Kablitz B, Wilde C, Franke P, Mehta N, Cameotra SS. 2002. Matrix-assisted laser desorption ionization-time of flight mass spectrometry of lipopeptide biosurfactants in whole cells and culture filtrates of Bacillus subtilis C-1 isolated from petroleum sludge. Appl Environ Microbiol 68: 6210-6219.

24. Roongsawang N, Thaniyavarn J, Thaniyavarn S, Kameyama T, Haruki M, Imanaka T, Morikawa M, Kanaya S. 2002. Isolation and characterization of a halotolerant Bacillus subtilis BBK-1 which produces three kinds of lipopeptides: bacillomycin L, plipastatin, and surfactin. Extremophiles 6: 499-506.

25. Duitman EH, Wycawski D, Boven LG, Venema G, Kuipers OP, Hamoen LW. 2007. Novel methods for genetic transformation of natural Bacillus subtilis isolates used to study the regulation of the mycosubtilin and surfactin synthetases. Appl Environ Microbiol 73: 3490-3496.

26. Teo AYL, Tan HM. 2005. Inhibition of Clostridium perfringens by a novel strain of Bacillus subtilis isolated from gastrointestinal tracts of healthy chickens. Appl Environ Microbiol 71: 4185-4190.

27. Chang ZQ, Oh BC, Rhee MH, Kim JC, Lee SP, Park SC. 2007. Polysaccharides isolated from Phellinus baumii stimulate murine splenocyte proliferation and inhibit the lipopolysaccharide-induced nitric oxide production in RAW264.7 murine macrophages. World J Micrbiol Biotechnol 23: 723-727.

28. Kim SY, Kim JY, Kim SH, Bae HJ, Yi HS, Yoon SH, Koo BS, Kwon MS, Cho JY, Lee CE, Hong SY. 2007. Surfactin from Bacillus subtilis displays anti-proliferative effect via apoptosis induction, cell cycle arrest and survival signaling suppression. FEBS Lett 58: 865-871.

29. Vollenbroich D, Ozel M, Vater J, Kamp RM, Pauli G. 1997. Mechanism of inactivation of enveloped viruses by the biosurfactant surfactin from Bacillus subtilis. Biologicals 25: 289-297.

30. Tsukagoshi N, Tamura G, Arima K. 1970. A novel protoplast bursting factor (surfactin) obtained from Bacillus subtilis IAM1213. I. The effects of surfactin on Bacilllus megaterium KM. Biochim Biophys Acta 196: 204-210.

31. Morán AC, Martínez, MA, Siñeriz F. 2002. Quantification of surfactin in culture supernatants by hemolytic activity. Biotechnol Lett 24: 177-180.

32. Kikuchi T, Hasumi K. 2002. Enhancement of plasminogen activation by surfactin $\mathrm{C}$ : augmentation of fibrinolysis in vitro and in vivo. Biochim Biophys Acta 29: 234-245.

33. Hwang MH, Lim JH, Yun HI, Rhee MH, Cho JY, Hsu WH, Park SC. 2005. Surfactin C inhibits the lipopolysaccharide-induced transcription of interleukin-1beta and inducible nitric oxide synthase and nitric oxide production in murine RAW 264.7 cells. Biotechnol Lett 27: 16051608.

34. Hwang MH, Chang ZQ, Kang EH, Lim JH, Yun HI, Rhee MH, Jeong KS, Park SC. 2008. Surfactin C inhibits Mycoplasma hyopneumoniae-induced transcription of proinflammatory cytokines and nitric oxide production in murine RAW 264.7 cells. Biotechnol Lett 30: 229-233. 